\title{
Assessment of Protective Antioxidant Mechanisms in some Ethno- Medicinally Important wild Edible Fruits of Odisha, India
}

\author{
Uday Chand Basak*, Ajay K Mahapatra and Satarupa Mishra
}

Regional Plant Resource Centre, $R$ and $D$ Institute of Forest and Environment Department, Govt. of Odisha, Bhubaneswar, India

\begin{abstract}
Fruits and vegetables have now been documented as nutraceuticals or functional foods useful for health and medical benefits including prevention and treatment of diseases. With the background of ethno medicinal evidences and the view to utilize the wild fruit resources of Odisha, India as functional food enriched with antioxidants, 4 wild edible fruits were studied for in vitro radical scavenging activity and antioxidant enzymes such as Peroxidase, Catalase and Superoxide dismutase (SOD) following standard methods. It was found that the fruit with highest DPPH scavenging activity is Antidesma ghaesembilla (1020.6 AEAC mg/100 g dwt) and the lowest recorded in Morinda tinctoria (235 AEAC mg/100 g dwt). The highest FRAP value was recorded in Antidesma ghaesembilla $(2114 \mu \mathrm{M}$ AEAC/g dwt) and the fruit with lowest FRAP value was Careya arborea (538 $\mu \mathrm{M} \mathrm{AEAC/g} \mathrm{dwt)} \mathrm{Antidesma}$ ghaesembilla showed the highest Peroxidase value of $1.12 \mathrm{OD} / \mathrm{min} / \mathrm{g}$ tissue wt while the lowest was found in Morinda tinctoria $\left(0.054 \mathrm{OD} / \mathrm{min} / \mathrm{g}\right.$ tissue wt). Catalase was found in high amounts in Antidesma ghaesembilla $\left(5.4 \times 10^{4}\right.$ $\mathrm{IEU} / \mathrm{g}$ fresh tissue), the lowest value was observed in Dillenia pentagyna $\left(1.2 \times 10^{4} \mathrm{IEU} / \mathrm{g}\right.$ fresh tissue). Similarly for superoxide dismutase (SOD), the highest value was recorded in Morinda tinctoria $(4.43 \Delta \mathrm{OD} / \mathrm{min} / \mathrm{mg}$ protein) and lowest in Careya arborea (1.12 $\Delta \mathrm{OD} / \mathrm{min} / \mathrm{mg}$ protein). Current research reveals that these wild edible fruits, especially Antidesma ghaesembilla are rich source of antioxidants and can further be subjected to identification of individual compounds responsible for such high antioxidant activity.
\end{abstract}

Keywords: Antioxidants; Catalase; Enzymes; Fruits; Peroxidase; Superoxide dismutase

\section{Introduction}

It is now well accepted fact that fruits and vegetables are nutraceuticals or functional foods [1]. Nutraceuticals are food or food products that are reported to provide health and medical benefits, including the prevention and treatment of disease. Besides the commercially grown and popularly consumed fruits, wild edible fruits can also be considered part of the continuum since they may be potential source of nutrients and antioxidants.

Antioxidant is a substance that has the ability to delay the oxidation of a substrate by inhibiting the initiation or propagation of oxidising chain reactions caused by free radicals. It plays important roles to prevent fats and oils from becoming rancid and protects human body from detrimental effects of free radicals [2]. Each cell in the body has adequate protective mechanisms against any harmful effects of free radicals i.e. superoxide dismutase (SOD), glutathione peroxidase, glutathione reductase, thioredoxin, thiols and disulfide bonding are buffering systems in every cell. $\alpha$-Tocopherol (vitamin E) is an essential nutrient which functions as a chain-breaking antioxidant which prevents the propagation of free radical reactions in all cell membranes in the human body. Ascorbic acid (vitamin C) is also part of the normal protecting mechanism. Other non-enzymatic antioxidants include carotenoids, flavonoids and related polyphenols, $\alpha$-lipoic acid, glutathione etc.

There are several methods to investigate the in vitro antioxidant potential of biological samples. These methods differ in the way the free radicals are scavenged by the sample molecules. In this study we have adopted the DPPH (2, 2-diphenyl-1-picrylhydrazyl) and FRAP (Ferric reducing antioxidant capacity) assay to evaluate the total antioxidant potential of the fruit pulp extracts. Similarly for the enzyme assays Peroxidase assay was carried out following Luhova et al. [3], Catalase following Beauchamp et al. [4].
The present research paper explores 4 ethno-medicinally important wild edible fruits namely Antidesma ghaesembilla, Careya arborea, Dillenia pentagyna and Morinda tinctoria for their in vitro free radical scavenging potential and antioxidant enzymatic activity.

\section{Materials and Methods}

\section{Materials}

Four wild edible fruits namely Antidesma gaesembilla, Careya arborea, Dillenia pentagyna and Morinda tinctoria were shortlisted and selected owing to their ethno-medicinal importance. Healthy and infection-free ripe wild fruits were collected from Similipal Biosphere Reserve (District Mayurbhanj), Odisha, India. Voucher specimens were identified in the institutional herbarium. A general account of the selected fruit plants and their uses is presented in Table 1.

\section{Methods}

Sample preparation for anti-oxidant activity: The fruits were cleaned and dried at $40^{\circ} \mathrm{C}$ (not exceeding $50^{\circ} \mathrm{C}$ ) following the suggestion by Khamsah et al. [5]. Then, the dried fruits were ground into fine powder using mortar and pestle. $1 \mathrm{~g}$ dried powder of each fruit was weighed and transferred into a beaker. $20 \mathrm{~mL}$ of solvent (i.e.

*Corresponding author: Uday Chand Basak Regional Plant Resource Centre $\mathrm{R}$ andD Institute of Forest and Environment Department, Govt. of Odisha Nayapalli, Bhubaneswar-751015, Odisha, India, Tel: 09437481352; E-mail: uc_basak07@yahoo.co.in

Received September 20, 2013; Accepted November 25, 2013; Published Decemeber 03, 2013

Citation: Basak UC, Mahapatra AK, Mishra S (2013) Assessment of Protective Antioxidant Mechanisms in some Ethno-Medicinally Important wild Edible Fruits of Odisha, India. Agrotechnol 2: 116. doi:10.4172/2168-9881.1000116

Copyright: $\odot 2013$ Basak UC, et al. This is an open-access article distributed unde the terms of the Creative Commons Attribution License, which permits unrestricted use, distribution, and reproduction in any medium, provided the original author and source are credited. 
Citation: Basak UC, Mahapatra AK, Mishra S (2013) Assessment of Protective Antioxidant Mechanisms in some Ethno-Medicinally Important wild Edible Fruits of Odisha, India. Agrotechnol 2: 116. doi:10.4172/2168-9881.1000116

Page 2 of 4

\begin{tabular}{|c|c|c|c|c|}
\hline S.No & Fruit Species & Local Name & Ethno medicinal Uses & Referances \\
\hline 1 & $\begin{array}{c}\text { Antidesma } \\
\text { ghaesembilla }\end{array}$ & Nuniari & $\begin{array}{c}\text { Fruit contains high amount } \\
\text { of vitamin C. }\end{array}$ & {$[12]$} \\
\hline 2 & Morinda tinctoria & Achhu & $\begin{array}{c}\text { There is greater demand } \\
\text { for fruit extract of Morinda } \\
\text { species in treatment for } \\
\text { arthritis, cancer, gastric } \\
\text { ulcer and other heart } \\
\text { diseases. }\end{array}$ & [13] \\
\hline 3 & Dillenia pentagyna & Rai & $\begin{array}{c}\text { Tribal folks use various } \\
\text { parts of the plant for the } \\
\text { treatment of ailments and } \\
\text { diseases like delivery } \\
\text { (stem), bone fracture } \\
\text { (bark), body pain (root), } \\
\text { piles (leaf), diabetes (bark), } \\
\text { diarrhea and dysentery } \\
\text { (bark). }\end{array}$ & [14] \\
\hline 4 & Careya arborea & Kumbhi & $\begin{array}{c}\text { The fruit extract is used } \\
\text { as decoction to promote } \\
\text { digestion. }\end{array}$ & [15] \\
\hline
\end{tabular}

Table 1: General account of 4 selected wild edible fruits and their ethno medicinal importance.

absolute methanol) was added into the beaker and the mixture was shaken using mechanical shaker for $24 \mathrm{~h}$ at room temperature. Each extract was filtered using Whatman No.1 filter paper. The filtrate was collected and the residue was re-extracted twice. The two extracts were then pooled. The solvents (i.e. absolute methanol) in the extract were removed under reduced pressure at $40^{\circ} \mathrm{C}$ using rotary evaporator. The extracts were collected and stored at $4^{\circ} \mathrm{C}$ until further uses.

DPPH radical method: The ability of the extract to scavenge the DPPH (2, 2-diphenyl-1-picrylhydrazyl) radical was evaluated as described in the literature [6]. The antioxidant content was determined using a standard curve of ascorbic acid $(0-10 \mu \mathrm{g} / \mathrm{mL})$. The results were expressed as $\mathrm{mg}$ of ascorbic acid equivalent antioxidant content (AEAC) per $100 \mathrm{~g}$ of fruit weight.

FRAP method: The total antioxidant activity was measured using Ferric reducing antioxidant power (FRAP) assay [7]. FRAP assay was determined based on the reduction of $\mathrm{Fe}^{3+}-\mathrm{TPTZ}$ to a blue coloured $\mathrm{Fe}^{2+}$ TPTZ. The FRAP reagent was prepared by mixing $300 \mathrm{mM}$ acetate buffer ( $\mathrm{pH}$ 3.6), $10 \mathrm{mM}$ TPTZ and $20 \mathrm{mM} \mathrm{FeCl}_{3} 6 \mathrm{H}_{2} \mathrm{O}$ in a ratio of $10: 1: 1$, at to $37^{\circ} \mathrm{C}$. FRAP reagent $(3 \mathrm{ml})$ was pipetted into test tubes. A total of $100 \mu \mathrm{l}$ of sample and $300 \mu \mathrm{l}$ of distilled water was then added to the same test tubes, and incubated at $37^{\circ} \mathrm{C}$ for $4 \mathrm{~min}$. Each sample was run in triplicate. Absorbance was measured at $593 \mathrm{~nm}$. FRAP value was calculated according to the equation:

FRAP $(\mathrm{mM})=0-4 \mathrm{~min}$ of $\triangle \mathrm{A} 593 \mathrm{~nm}$ of test sample $/ 0-4 \mathrm{~min}$ of $\triangle \mathrm{A} 593 \mathrm{~nm}$ of standard samplex[standard] $\mathrm{mM}$

Peroxidase activity-Peroxidase activity was measured by a modified method of Angelini et al. [8] as described by Luhova et al. [3] taking O-dinisidine.

Superoxide Dismutase (SOD)-All extracts were assayed for SOD activity photochemically, using the assay system consisting of methionine, riboflavin, and NBT [4].

Catalase-One unit of catalase activity is defined as that amount of enzyme which breaks down I $\mu \mathrm{mol}$ of $\mathrm{H}_{2} \mathrm{O}_{2} /$ min under the defined assay conditions [9] with slight modifications. Five milliliters of the assay mixture for the catalase activity comprised: $0.2 \mathrm{M}$ of phosphate buffer ( $\mathrm{pH} 6.8$ ), $0.4 \mathrm{~N}$ of $\mathrm{H}_{2} \mathrm{O}_{2}$, and $\mathrm{I} \mathrm{ml}$ of the twice diluted enzyme extracted. After incubation at $25^{\circ} \mathrm{C}$ for I min, the reaction was stopped by adding $10 \mathrm{ml}$ of $2 \%(\mathrm{v} / \mathrm{v}) \mathrm{H}_{2} \mathrm{SO}_{4}$, phosphate buffer and the residual $\mathrm{H}_{2} \mathrm{O}_{2}$ was titrated against $0.01 \mathrm{~N} \mathrm{KMnO}_{4}$ until a faint purple color persisted for at least $15 \mathrm{sec}$. A control was run at the same time in which the enzyme activity was stopped at "zero" time.

\section{Results and Discussion}

\section{Antioxidant capacity}

The antioxidant capacity measured by DPPH and FRAP assay demonstrates that the fruit pulp extracts have different free radical scavenging ability for the above methods. This finding corroborates with the findings of Pellegrini et al. [10]. The findings are presented in Table 2 and Figure 1.

\section{DPPH radical scavenging assay}

The DPPH test is the oldest indirect method for determining the antioxidant activity which is based on the ability of the stable free radical 2, 2-diphenyl-1-picrylhydrazyl to react with hydrogen donors including phenols [11]. The antioxidant capacity of 4 ethno medicinally important wild edible fruits evaluated by DPPH assay and expressed as AEAC or ascorbic acid equivalent antioxidant capacity, ranged between 235 and 1020.6 AEAC mg/100 g. The DPPH assay depicts that the fruit with highest DPPH scavenging activity is Antidesma ghaesembilla (1020.6 AEAC $\mathrm{mg} / 100 \mathrm{~g}$ ) and the lowest recorded in Morinda tinctoria (235 AEAC mg/100 g).

\section{FRAP antioxidant assay}

The FRAP assay measures the ability of antioxidant to reduce $\mathrm{Fe}$ (3+) to $\mathrm{Fe}(2+)$. FRAP values were expressed as $\mu \mathrm{M} \mathrm{AEAC/g} \mathrm{dw.} \mathrm{The}$ highest FRAP value was recorded in Antidesma ghaesembilla $(2114 \mu \mathrm{M}$ AEAC/g dw) followed by Dillenia pentagyna (1099 $\mu \mathrm{M}$ AEAC/g dw) The fruit with lowest FRAP value was Careya arborea ( $538 \mu \mathrm{M} \mathrm{AEAC/g} \mathrm{dw).}$

\begin{tabular}{|l|l|l|l|}
\hline S.No & Fruit Sample & $\begin{array}{l}\text { DPPH } \\
\text { AEAC } \mathbf{~ m g / 1 0 0 ~ g ~ d r y ~} \\
\text { weight }\end{array}$ & $\begin{array}{l}\text { FRAP } \\
\boldsymbol{\mu} \text { M AEAC/g dry } \\
\text { weight }\end{array}$ \\
\hline 1 & $\begin{array}{l}\text { Antidesma } \\
\text { ghaesembilla }\end{array}$ & $1020.66 \pm 3.21$ & $2114 \pm 1.00$ \\
\hline 2 & Careya arborea & $850.66 \pm 3.00$ & $538 \pm 0.01$ \\
\hline 3 & Dillenia pentagyna & $550 \pm 3.60$ & $1099 \pm 4.00$ \\
\hline 4 & Morinda tinctoria & $235 \pm 13.20$ & $724.5 \pm 3.70$ \\
\hline
\end{tabular}

Values are mean $\pm S D(n=3)$

Table 2: DPPH and FRAP assay of 4 ethno medicinally important wild edible fruits of Odisha.

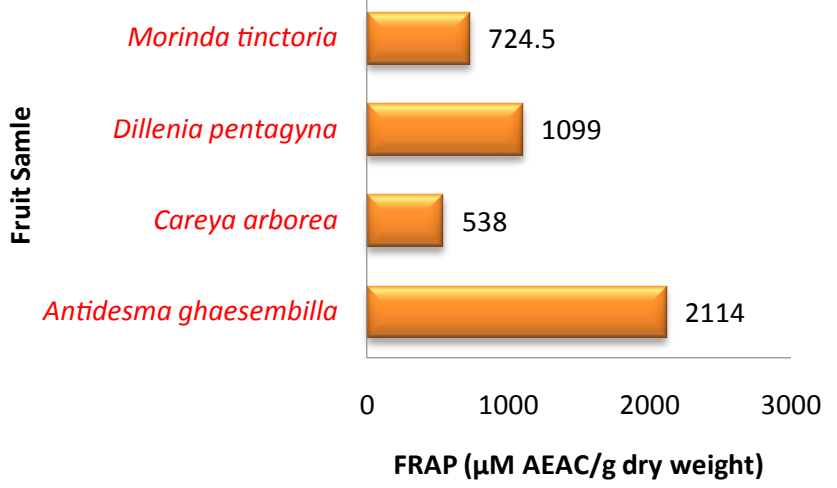

Figure 1: FRAP assay of 4 ethno medicinally important wild edible fruits of Odisha. 
Citation: Basak UC, Mahapatra AK, Mishra S (2013) Assessment of Protective Antioxidant Mechanisms in some Ethno-Medicinally Important wild Edible Fruits of Odisha, India. Agrotechnol 2: 116. doi:10.4172/2168-9881.1000116

Page 3 of 4

\section{Antioxidant enzyme assay}

The findings of Peroxidase, Catalase and superoxide dismutase assay were revealed in Table 3 and Figures 2-4.

\section{Peroxidase assay}

Antidesma ghaesembilla showed the highest Peroxidase value of $1.12 \mathrm{OD} / \mathrm{min} / \mathrm{g}$ tissue weight while the lowest was found in Morinda tinctoria $(0.054 \mathrm{OD} / \mathrm{min} / \mathrm{g}$ tissue weight). Careya arborea recorded 0.09 while Dillenia pentagyna showed $0.76 \mathrm{OD} / \mathrm{min} / \mathrm{g}$ tissue weight of Peroxidase activity.

\begin{tabular}{|l|l|l|l|l|}
\hline S.No & Fruit & $\begin{array}{l}\text { Peroxidase } \\
\text { (OD/min/g } \\
\text { tissue wt) }\end{array}$ & $\begin{array}{l}\text { Catalase } \\
\text { (IEU) }\end{array}$ & $\begin{array}{l}\text { SOD }(\Delta \text { OD/min/ } \\
\text { mg protein) }\end{array}$ \\
\hline 1 & $\begin{array}{l}\text { Antidesma } \\
\text { ghaesembilla }\end{array}$ & 1.12 & $5.4 \times 10^{4}$ & 2.66 \\
\hline 2 & Careya arborea & 0.09 & $3.1 \times 10^{4}$ & 1.12 \\
\hline 3 & Dillenia pentagyna & 0.76 & $1.2 \times 10^{4}$ & 1.9 \\
\hline 4 & Morinda tinctoria & 0.054 & $2.7 \times 10^{4}$ & 4.438 \\
\hline
\end{tabular}

Table 3: Antioxidant enzyme assay of 4 ethno medicinally important wild edible fruits of Odisha.

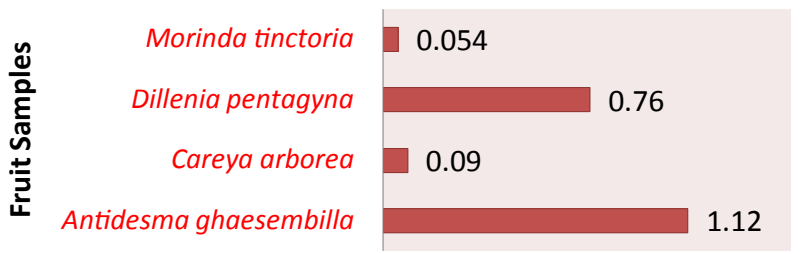

\section{Peroxidse (OD/min/g tissue wt)}

Figure 2: Peroxidase assay of 4 ethno medicinally important wild edible fruits of Odisha.

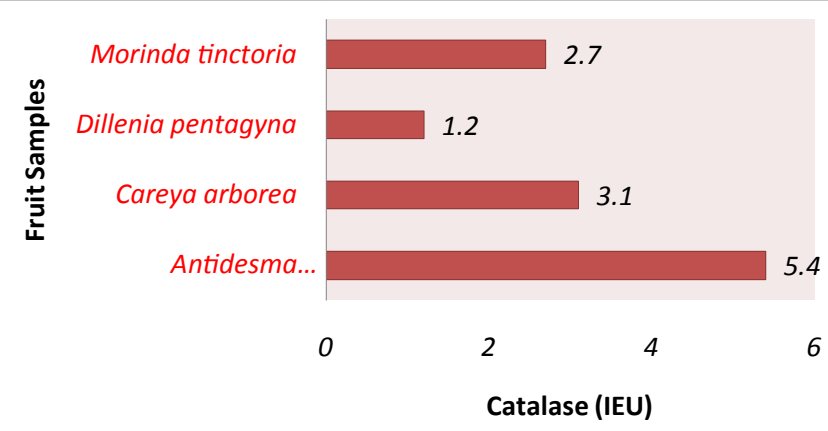

Figure 3: Catalase assay of 4 ethno medicinally important wild edible fruits of Odisha.

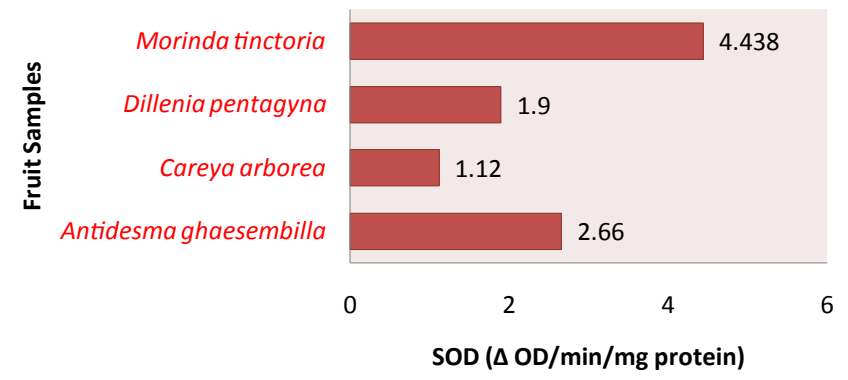

Figure 4: Superoxide dismutase (SOD) assay of 4 ethno medicinally important wild edible fruits of Odisha.

\section{Catalase assay}

Catalase helps in breaking down hydrogen peroxide into water and oxygen. Highest Catalase activity was found to be again in Antidesma ghaesembilla $5.4 \times 10^{4}$ IEU followed by Careya arborea $3.1 \times 10^{4}$ IEU and subsequently Morinda tinctoria $2.7 \times 10^{4}$ IEU. The lowest value was observed in Dillenia pentagyna $1.2 \times 10^{4} \mathrm{IEU}$.

\section{Superoxide Dismutase assay (SOD)}

SOD ranged between 1.12 and $4.43 \Delta \mathrm{OD} / \mathrm{min} / \mathrm{mg}$ protein. The highest being Morinda tinctoria ( $4.43 \Delta \mathrm{OD} / \mathrm{min} / \mathrm{mg}$ protein) followed by Antidesma ghaesembilla $2.66 \Delta \mathrm{OD} / \mathrm{min} / \mathrm{mg}$ protein) and thereby lowest in Careya arborea (1.12 $\Delta \mathrm{OD} / \mathrm{min} / \mathrm{mg}$ protein).

This study establishes that all the 4 wild edible fruits can serve as supplements of natural antioxidants. But notably Antidesma ghaesembilla is the fruit that is not only relishing in taste but is a powerhouse of antioxidants.

\section{Conclusion}

Four wild edible fruits namely Antidesma ghaesembilla, Careya arborea, Dillenia pentagyna and Morinda tinctoria were analyzed for their total antioxidant capacity through in vitro radical scavenging assays such as DPPH and FRAP and antioxidant enzyme content for three enzymes namely Peroxidase, Catalase and superoxide dismutase (SOD). The result so obtained clearly signifies that these fruits are rich source of antioxidants (both enzymatic and non-enzymatic). Since antioxidants play crucial role in prevention of many degenerative diseases, these fruits have the scope to be included in functional foods that provide natural antioxidant supplement.

\section{Acknowledgements}

The authors are thankful to the Forest and Environment Department, Govt. of Odisha for supporting this institutional project work under State Plan Grant.

\section{References}

1. Shui G, LP Leong (2006) Residue from star fruit as valuable source for functional food ingredients and antioxidant nutraceuticals. Food Chemistry 97 277-84.

2. Almey A, Khan AA,Ahmed Jalal, Syed Zahir C,Mustapha Suleiman K et al. (2010) Total phenolic content and primary antioxidant activity of methanolic and ethanolic extracts of aromatic plants' leaves. International Food Research Journal. 17: 1077-84

3. Luhova L, Lebeda A, Hedererova, Pec P (2003) Activities of amine oxidase, Peroxidase and catalase in seedlings of Pisum sativum L. under different light conditions. Plant Soil Env 49: 151-157.

4. Beauchamp C, Fridovich I (1971) Superoxide dismutase: improved assays and an assay applicable to acrylamide gels. Anal Biochem 44: 276-287.

5. Khamsah SM, Akowah G, Zhari I (2006) Antioxidant activity and phenolic content of Orthosiphon stamineus Benth from different geographical origin. J Sustainability Sci and Management 1: 14-20.

6. Meda, A, Lamien CE, Romito M, Millogo J; Nacoulma OG (2005) Determination of the total phenolic, flavonoid and proline contents in Burkina Fasan honey, as well as their radical radical scavenging activity. Food Chem.91: 571-577.

7. Benzie IFF, Strain JJ (1999) Ferric reducing/antioxidant power assay: direct measure of total antioxidant activity of biological fluids and modified version for simultaneous measurement of total antioxidant power and ascorbic acid concentration. Methods in Enzymology 299: 15-27.

8. Angelini R, Manes F, Federico R (1990) Spatial and functional correlation between diamine-oxidase and peroxidase activities and their dependence upon de-etiolation and wounding in chick-pea stems. Planta 182: 89-96.

9. Chance B, Maehly AC (1955) Assay of catalase and peroxidases. Methods Enzymol, 2: 764-775. 
Citation: Basak UC, Mahapatra AK, Mishra S (2013) Assessment of Protective Antioxidant Mechanisms in some Ethno-Medicinally Important wild Edible Fruits of Odisha, India. Agrotechnol 2: 116. doi:10.4172/2168-9881.1000116

10. Pellegrini N, Serafini M, Colombi B, Del Rio D, Salvatore S, et al. (2003) Total antioxidant capacity of plant foods, beverages and oils consumed in Italy assessed by three different in vitro assays. J Nutr 133: 2812-2819.

11. Roginsky V, Lissi EA (2005) Review of methods to determine chain-breaking antioxidant activity in food. Food Chem, 92: 235-254.

12. Nazarudeen $A$ (2010) Nutritional composition of some lesser-known fruits used by ethnic communities and local folks of Kerala. Ind J Traditional Knowl 9: 398402.
13. Mathivanan N, Surendiran G, Srinivasan K, Malarvizhi K (2006) Morinda pubescens JE Smith (Morinda tinctoria Roxb) fruit extract accelerates wound healing in rats. J Med Food 9: 591-593.

14. Dubey PC, RLS Sikarwar, KK Khanna, AP Tiwari. Ethnobotany of Dillenia pentagyna Roxb. In Vindhya region of Madhya Pradesh, India. Niscair Online Periodicals Repository. 8: 546-548

15. Gupta PC, Sharma N, Rao ChV (2012) Pharmacognostic studies of the leaves and stem of Careya arborea Roxb. Asian Pac J Trop Biomed 2: 404-408. 